\title{
UK's Regulations on Foreign Ownership of Land-Historical and Practical Perspectives
}

\author{
Xiaojing Qin* \\ Assistant Professor, School of Law \\ Beijing Normal University, China \\ Vis iting Scholar of LauterpachtCentre for International Law \\ University of Cambridge, UK \\ Email: 11112012110 [AT] bnu.edu.cn
}

\begin{abstract}
This article provides an overview of alien land policies in the UK. It firstly identify the historical background and legal framework associated with UK's Regulations on Foreign Ownership of Land, which are then drawn on to address the extent to which immigration law affects the property rights of aliens. It further discusses the regulation on acquisition of land by alien enemies to which national security issues are related. The concluding part will establish an integrated framework regarding how the UK has responded to political, economic and social concerns in making and modifying its alien land law.
\end{abstract}

Keywords---- Foreign ownership of land; acquisiton of land; housing rights; immigration; national security

\section{INTRODUCTION}

Thus far, not many studies have addressed the is sue of foreigners' land ownership rights in the UK. Most havean extensive focus on the economic value of real es tate investment, such as global property investment and finance and international property portfolios, in the context of the current legal framework. The deeper es tablis hing and social forces shaping foreign real es tate investment are hardly examined. This article will examine the UK's regulation on foreign land ownership from a theoretical pers pective. Section 2 will go back to the roots of the problemby looking at the his torical evolution of alien land law in UK. In Section 3, the study moves on to examine the extent to which immigration law affects the property rights of aliens. Section 4 discusses the regulation on acquisition of land by alien enemies to which national security issues are related. Section 5 concludes.

\section{HISTORICAL OVERVIEW OF ALIEN LAND LAW IN THE UK: A POLITICAL PERSPECTIVE}

A his torical view of alien land law under the common law systemis much valued as the modern land systemhas a direct lineage to his torical common law and many countries still maintain traditional legal principles. Therefore a study of land law history is of great practical relevance.

\subsection{The Com mon Law Tradition of Alien Land Disability}

The his tory of alien land ownership dis ability can be traced back to the period of the Hundred Years 'War. ${ }^{1}$ Such a notion first entered into common law when the English king captured the lands of the French and Normans in England in retaliation for their occupation of the king's land in Normandy. ${ }^{2}$ The English king had previously possessed the Duchy of Normandy, which earlier still had been part of France. Frenchmen later occupied Normandy and thelords in the Duchy thus changed their allegiance to the new ruler, ${ }^{3}$ thus prompting the retaliation by the English king. The king's further efforts to retain possession of his remaining land in France finally developed in to the Hundred Years' War. ${ }^{4}$ Early on in the war, the English king was fairly optimistic about his chance of success and even promised a return of captured land to the Normans and Frenchmen, when the war was over. ${ }^{5}$ But the war was finally ended with the expulsion of the English from France, tuming

*This research is funded by China Scholarship Council. All errors are my own.

\footnotetext{
${ }^{1}$ Notes, "Conflict between Local and National Interests in Alien Landholding Restrictions" (1948) 16 The University of Chicago Law Review 315, p.316

${ }^{2}$ Ibid.

${ }^{3}$ Ibid.

${ }^{4}$ Ibid.

5 Ibid., pp.316-7.
} 
the Frenchmen in England into aliens rather than the expected tenants of the English king. ${ }^{6}$ The notion that aliens should not be allowed to hold land in England, and later in the UK, arose during that period and has remained as a common law tradition. ${ }^{7}$ After the war, the king granted land to tenants in exchange for their promise to provide required services, including military services, ${ }^{8}$ possibly as a result of his fear of recurring war. Aliens came about as a consequence of this demanded allegiance to the king; they were men who were presumed to have divided loyalty to an alien sovereignty as well as or instead of to the feudal state, and were barred frompos sessing land. ${ }^{9}$ This then became a common law principle which dominated the whole feudal era.

Land was the most valuable resource sustaining early feudal society and was exclusively owned by the king and feudal lords. When this social ruling class granted land to the community, in exchange for the submis sion of various services, only those who were fully allegiant to their authority were entitled to possess it. Those citizens who obeyed the lords and king of England gained the right to farm the land as tenants, ${ }^{10}$ while aliens presumed to have allegiance to another state were excluded from such rights. ${ }^{11}$

This general principle was further clarified through a set of regulations and monitoring facilities. The fundamental rule of the common law doctrine was that aliens were banned fromholding land, eith erby purchase or descent. ${ }^{12}$ Their title was subject to forfeiture by escheat in the case of purchase and was void altogether in the case of descent.

Firstly, aliens who purchased land might have to forfeit it, at the request of the state, at any time during their lifetime. ${ }^{13}$ Escheat proceedings instituted by the state were known as "inquest of office", requiring merely that the state proved the land was owned by an alien, and leaving the defendant to prove otherwise ${ }^{14}$ Upon proof that the person claiming title to the land was an alien, thes tate had a right to divest it, without any particular reason, to the feudal lord. Therefore, the aliens merely enjoyed a defeasible title that was subject to challenge at any time. ${ }^{15}$ Secondly, aliens who remained un-naturalized at their death were deprived of the ability to inherit through the legal scheme of intestate succession. ${ }^{16}$ Thirdly, just as citizens could not inherit land fromaliens under the state's intestate succession law, neither could aliens inherit land from citizens by the operation of law as there is a lack of "inheritable blood" under both circumstances for the inheritance. ${ }^{17}$ The land automatically es cheated to the state unless a more remote re lative who was a citizen could be found. ${ }^{18}$

Furthermore, the state could take land vested in trustees for aliens as if it was held directly by the aliens. ${ }^{19}$ In terms of right to lease, the common law granted preferential treatment to alien merchant friends, allowing them to lease property during their lives and while residing within the realm; ${ }^{20}$ but it claimed that leases or agreements to lease ${ }^{21}$ to alien artificers or handicraftsmen were invalid. ${ }^{22}$ The only way for these aliens to acquire leasehold property was through the assignment of a subsisting lease.

A corporation was not allowed to purchase and hold land in a corporate capacity without a licence to hold it in mortmain ${ }^{23}$ or under the special provis ions of an Act of Parliament. Purchases by individuals who were unincorporated had to be made "in their private capacities and individual names". ${ }^{24}$ The parson and churchwardens were traditionally eligible to purchase land as corporations, in the name of churchwardens and overseers in some matters relating to the Poor Laws, ${ }^{25}$ and to

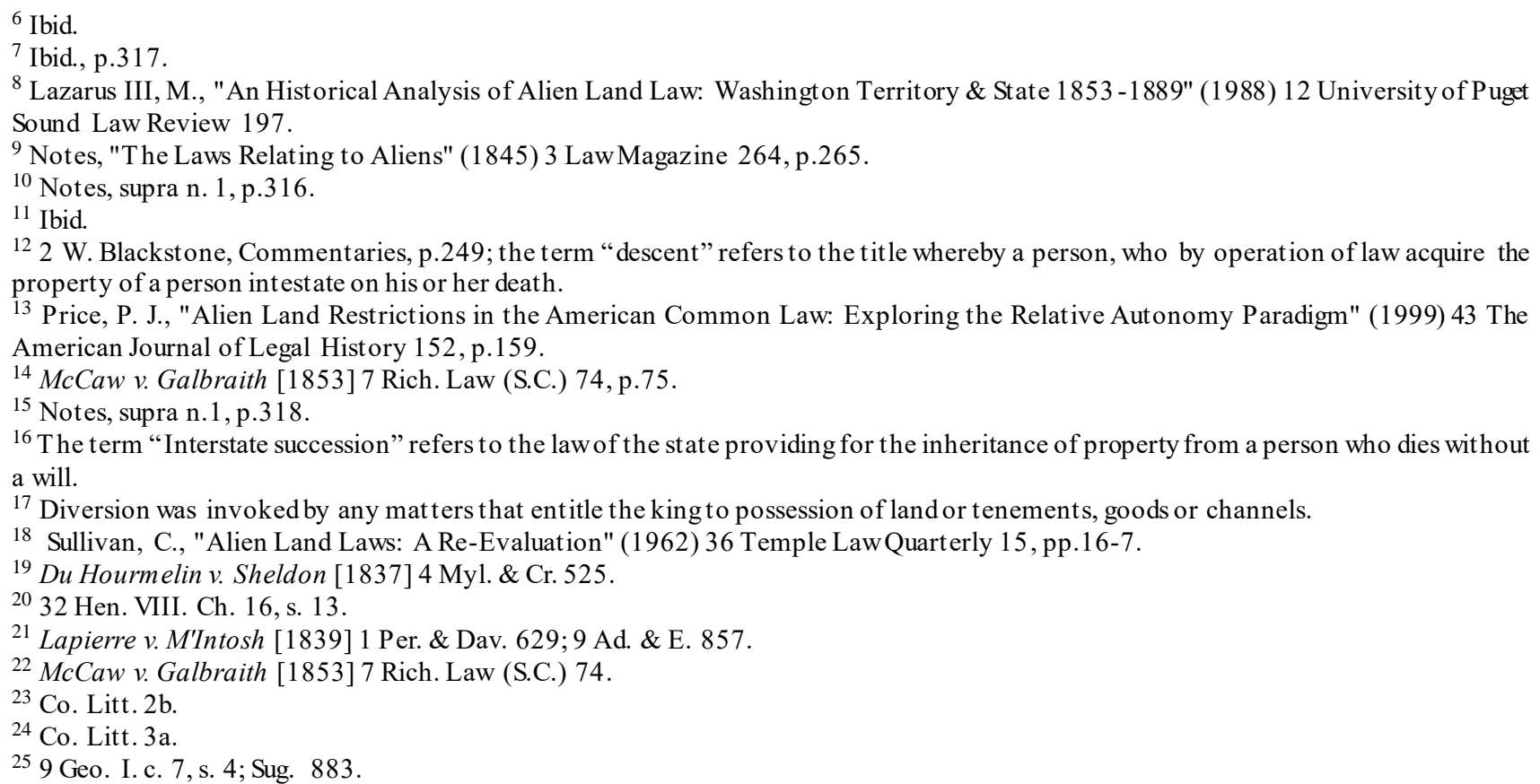


Education. It was further stated that:

[A] purchase by, eo nomine, the inhabitants of a place, or the parishioners or churchwardens of a parish, is bad; so is a similar purchase by, or grant to, the commoners of a waste. ${ }^{26}$

\subsection{Improvem ents to Alien Land Law}

\subsubsection{The Privilege of Land Ownership Granted to Alien Merchants}

The development of trade in the fourteenth century resulted in aliens becoming more important merchants in England. ${ }^{27}$ The policies ofEdward III and Richard II started to encourage trade by granting alien merchants the freedom to trade and some other privileges of natural born citizens. ${ }^{28}$ An act of naturalization and the denization process were used for this purpose. These privileges, in most cases, involved the right to purchase land which could notbe divested upon an inquest of office found by the state and therefore secured the aliens' land titles. ${ }^{29}$

An act of naturalization was obtained through the introduction of a private bill into parliament by the king and conveyed alien merchants rights similar to those of a natural born citizen. ${ }^{30}$ The alien, by completing the naturalization process, became a naturalized citizen and could acquire the rights to real property previously granted only to citizens, including inheritance rights and the right to devise. ${ }^{31}$

The king, in pers on, shall by denizen patent, provide aliens a granting of denization, with particular privileges specified. ${ }^{32}$ Thes e privileges conferred on aliens the right to buy land without ris k of defeasance by escheat. After denization, the alien could both purchase and hold land in trust and was also entitled to land purchased before denization if the Crown endorsed the es tate in the letters of patent of denization. ${ }^{33}$ Such a privilege could be passed on to any children born after the granting of the denization. ${ }^{34}$ Although aliens could go through the formalities of denization to secure their land purchase rights, few did that as the law court started to offer themprotection in respect to such rights. Aliens were only dis advantaged in the matters of taxes and the inheritance of property. ${ }^{35}$

\subsubsection{The ResidentialProperty Rights Granted to Alien Friends}

Although the Crown's approval was still not granted to aliens in generally, friendly alien merchants were granted more freedomin the form of the right to reside, that is, to hold a house for habitation. More specifically, an alien merchant was allowed to rent or lease a house for habitation. ${ }^{36}$ The privilege to hold a lease on a house was considered to convey no es taterights and therefore its ratification involved only min or infringements with respect to the feudal principle of tenure. ${ }^{37}$ Although the rule only offered the alien the right to inhabit a house, it repres ented a step towards the possibility of further relaxations. Such a possibility came into effect with the enactment of $7 \& 8$ Vict. c.66. $\S 5$ of the statute, which e nabled any alien friend:

...by grant, lease, demise, bequest, representation or otherwise, to take and hold any lands, houses or other tenements for purpose of residence or occupation by himor her, or his or her servants, or for the purpose of any business, trade and manufacture for any term of years not exceeding twenty-one years, as fully and effectually to all intents and purposes, and with the same rights, remedies, exemptions and privileges, except the right to vote for members of parliament, as if he were a naturalborn subject. ${ }^{38}$

\footnotetext{
${ }^{26}$ Co. Litt. 3 a.

${ }^{27}$ Kershaw, R. and M. Pearsall, Immigrants and Aliens: A Guide of Sources on UK Immigration and Citizenship, 2nd ed., (UK National Archives 2004), p.97.

${ }^{28}$ Ibid.

${ }^{29}$ See Rex v. Holland [1792] 4 D. \& E. 691; see also Co. Litt. 2b. the term "Inquest of office found" was an inquiry made by the King's officers concerning any matters that entitle the king to possession of land, usually because the land was held by an alien or because the death of the landholder left no heirs capable of taking the land, see Notes, supra n. 1, p.318.

${ }^{30}$ Kershaw and Pearsall, supra n. 27, p.55.

31 The term "devise" refers to the disposition of real property by will.

${ }^{32}$ Kershaw and Pearsall, supra n. 27,p.55.

${ }^{33}$ Fourdrin v. Gowdey [1834] 3 My. \& K. 383, 40 Eng. Rep. 146.

${ }^{34}$ Kershaw and Pearsall, supra n. 27, p.55.

${ }^{35}$ Ibid., pp.55 and 59.

${ }^{36}$ See $4 \& 5$ Vict. c. 38 , s. 8.

${ }^{37}$ Notes, surpa n. 9, p. 265 .

$387 \& 8$ Vict. c. $66, \S 5$.
} 
The right to hold a house for inhabitation under this law was extended to allow aliens to hold land for any commercial purposes, and for a longer, defined period of twenty-one years. The implication of Section $\S 5$ can by no means be underestimated. While the previous regulation regarding houses of habitation was a mech anism to facilitate alien residence, this statute was enacted to encourage commercial transactions by aliens. The recognition of the significance of land as the precondition to initiate commercial undertakings was explicitly expres sed in the new statute. As Montesquieu puts it, "the English have made the protection of foreign merchants on ef the articles of their national liberty" ${ }^{39}$ The greater fostering of foreign commerce, the permanent s truggle for liberal trading and the full recognition of the inheren t interaction between landholding freedom and commercial prosperity, all helped to push England into the new era ahead of many of its competitors and rewarded it with economic superiority and political pre-eminence for many years.

\subsection{Full Liberalization}

After the industrial revolution, Britain became more active in expanding its foreign trade. The growth of trade and the increase in the number of alien traders rais ed is sues concerning their access to and use of land necessary for them to stay and conduct business in the country. Without the free use ofland, their business had no location in which to be established. The relaxation of alien landholding rights became the shared requirement of both the alien merchants themselves and their co-operators in Britain. Finally, another statute was enacted to fully relax alien landholding restrictions, placing aliens on the same footing as natural-born British citizens. $§ 2$ of the Naturalis ation Act of 1870 stated:

[R]eal and pers onal property of every description may be taken, acquired, held and dis posed of by an alien in the same manner in all respects as by a natural-born British subject; and a title to real and personal property of every description may be derived through, from, or in succession to an alien, in the same manner in all respects as through, from or in succession to a natural-born British subject. ${ }^{40}$

With this, aliens acquired the same land rights as British citizens and could carry out their commercial undertakings under the guarantee that they could use the land required. Bus iness land rights tended to be more secure and efficient than they had been before. The legal affirmation of alien land rights, again, removed all concerns and provided strong incentives for commercial interactions, which ultimately contributed further to the great prosperity of the British economy in the long run.

As the UK is still in the transitional period of leaving the EU, it is still subject to the EU's existing rules on foreign land ownership. The implementation of the EU's Principles on the freedom of workers, establishment and services in the UK has guaranteed the elimination of all restrictions applied to EU nationals in respect of land owners hip, although when it comes to social housing and housing assistance, EU nationals are still subject to a residential requirement under UK domestic law. On the other hand, while the EC treaty has in certain ways allowed memberstates to maintain res trictions against nationals of non-EU members in respect of the acquis ition of real es tate, in fact no restrictions are applied in the domestic legislation of the UK, apart from in the case of the allocation of social housing. In other words, the UK has achieved full liberalization in respect of the acquisition of land ownership, both for EU nationals and non-EU nationals, with the exception of the differential treatment applied in the area of social housing.

\subsection{Conclusion}

Over time, the notion of allegiances has changed considerably. To begin with, allegiance was recognized as the natural and indelible tie between the state and its subjects. Aliens failed to possess such a tie and were completely excluded from swearing their allegiance to the English king. However, changing social circumstances caused the Crown to allow temporary allegiance in order to grant alien merchants a reasonable footing for a short-term stay in England. ${ }^{41}$ Can this change be attributed to the fact that aliens improved their allegiance to the state under the new social environment? This would be hard to prove, and certainly the feudal state would not have known at the time. But the state still claimed that aliens had temporary allegiance and could thus hold a lease on land. The reasonable explanation for such a change in policy is that the state did not really care about the existence of allegiance as a precondition for granting land privileges. If the state felt that it would be disadvantaged by relaxing its land policy on aliens, common sense dictates that it would not have proceeded with such a policy, especially given its high political risk. As the state was willing to grant aliens theright to use its land, it should have benefited rather than been disadvantaged by such a policy. When conflicting int erests arose, the definition of allegiance was altered. Allegiance was only one excuse by which the state could defend its policy. More critically, the notion of allegiance was taken as a tool to facilitate the changed national interests of the state. What really matters was not the notion itself, but the state's objective behind it. The elements of allegiance, regardless of their

\footnotetext{
${ }^{39}$ Notes, supra n. 9 , p. 265 .

$4033 \& 34$ Vict.c. $14, \S 2$.

${ }^{41}$ Holdsworth, W., A History of English Law Vol. 9, (Methuen and Co. 1926), p.97.
} 
importance, were not taken into account in the state's rules concerning alien landholding. The dominant argument was whether there was a good incentive to promote such a notion. The moral spirit of allegiance, even in the policy-making process of the ancient state, was not given much consideration. In a modern society, to recall such a concept which was discarded by the feudal state makes no sense, and is likely to lead to the impairment of economic development. Holding onto such a notion and declaring it to be the tradition of common law also seems to be a mis reading of his tory.

Shaped by the new social settings in the later feudal society, the test of allegiance evolved from a general nationality standard to an individual standard based on the activities of aliens. While it was the result of trading ties, this evolution also brought about a more rational view with respect to the individual nature of allegiance. The individual criterion of allegiance had direct influences on the state's alien policy-making process. Based on such a criterion, the state established alien rights and liabilities on an individual basis, rather than drawing an absolute line based upon the political relations between states. ${ }^{42}$ Such a standard enabled the state to receive economic benefits, while still identifying its true enemies. ${ }^{43}$ The same rule may apply to modern states, as they perform similar duties despite the change in eras. As allegiance is a notion with individual character, if states assume all aliens lack such a virtue and cut off their landholding rights based on a nationality standard, they may pay huge economic costs in return for guarding again st only a tiny portion of alien enemies.

All these changes can be attributed to the growing commercial interaction among states and their continual efforts to promote it. Trade interes ts pushed Britain to set as ide certain political values or reconsider them in a more adaptive way. The land is suewas a central target of such efforts, due to its value as the necessary componentoftrade. Therefore, almost every time the trade environment developed, aliens' rights to hold land increased. Modern economic prosperity in a wider, globalized dimension should, then, raise the demand for the relaxation of domestic real estatemarkets to a greater extent, which has been fully recognized by history.

\section{ALIEN HOUSING RIGHTS IN THE UK AND THEIR IMPACT ON IMMIGRATION LAW}

The effect of immigration on housing has historically acted as one of the primary forces behind the introduction of several fundamental legis lative reforms on immigration. ${ }^{44}$ This section seeks to present a general analysis of the forces that have shaped the country's policy on housing allocation to aliens and new immigrants through its history. It will also examine the current social housing policy applied to foreign residents.

\subsection{Historical Overview of the Impact of Alien Housing Rights on Im migration Law}

The imperial ideal did not dis appear with the end of colonization but in fact strengthened in the political circles of Britain. The favorable treatment of colonial immigrants was regarded as a consolation, devised to maintain the almost collapsing imperial ideal, symbolized as an indicator of first-class status in the world. Such a conception seemed to be needed even more with Britain's power eclipse by America. ${ }^{45}$

However, the dis tressing impact of the increasing number of immigrations, es pecially the pressure they placed on housing and employment, aroused the attention of the Home Secretary, who later submitted reports to the cabinet to consider the possibility of imposing immigration restrictions. ${ }^{46}$ Therefore, in a draft bill of 1955, it suggested the introduction of the housing certificate as a means of immigration control ${ }^{47}$ This type of housing permit required immigrants to prove to immigration officers that they had arranged suitable accommodation in the UK. This had the effect of limiting the influx. However, it was found to be quite impractical as local authorities were able to is sue fewer housing certificates and therefore cut down on immigration from the old commonwealth, which was nota desired outcome for the UK. ${ }^{48}$

In short, the problem of housing was the area most strongly felt by the public due to the growth of immigration numbers. It has been suggested by the national authority that the need to release housing pressure led directly to the immigration control introduced by the Housing Act $1961 .{ }^{49}$ The Commonwealth Immigration Act 1962 was another response to the perceived heavy influx of immigrants. It tightened the immigration policies by only permitting those with governmentis sued work vouchers, and their dependents, to settle.

\footnotetext{
42 Ibid., pp.99-103.

${ }^{43}$ Ibid.

${ }^{44}$ Spencer, I. R. G., British Immigration Policy since 1939: the Making of Multi-racial Britain, (Routledge 1997), p.112.

45 Coleman, D. A., "U.K. Statistics on Immigration: Development and Limit ations" (1987) 21 International Migration Review 1138, p. 1160 .

${ }^{46}$ Spencer, supra n. 44, p. 108 .

${ }^{47}$ Ibid., p. 110.

${ }^{48}$ Working Party Report to the Ministerial Committee, “Housing Certificates for Intending Immigrants” (11 April 1961) CAB134/1469.

${ }^{49}$ Spencer, supra n. 44, pp.108-12.
} 
After this, there was a strong degree of anti-alien sentiment in the community. It was almost impossible for aliens to buy property even if a sufficient amount of capital was offered. Mortgage lenders automatically labeled them as having low creditworthiness. ${ }^{50}$ The powerful social pressure against renting houses to aliens and the bad reputation that came from doing so made landlords reluctant to take the risk. ${ }^{51}$ Landlords often cited the racial discrimination of other residents as a tactful excuse for refusing to rent property to them. ${ }^{52}$ The desperate aliens were left no alternative except for the cheapest urban areas discarded by the local people, such as, Moss Side in Manchester, Handsworth in Birmingham. ${ }^{53}$ Although they were officially allowed to apply for council housing, there was little likelihood of it being allocated to themand any such luck was always accompanied by protests from the public. ${ }^{54}$ Throughout the whole process, the racial discrimination and hard-line attitudes of white Britain were directly related to the poor housing conditions of immigrants ${ }^{55}$ Housing was just one aspect that epitomized the mis erable downside for aliens living in the UK. The key problem lay in the strong racial dis crimination, embedded deeply in the local society, rather than in the perceived housing demand itself.

The Immigration Act 1971 finally put commonwealth citizens on essentially the same basis as foreign citizens, and they were thus excluded froms ocial housing schemes. Under the 1971 act, only persons who had right of abode in the UK were free from immigration control. These pers ons included citizens of the UK and its colonies who had acquired British citizenship by birth, adoption, regis tration or naturalization in the UK, or commonwealth citizens with a UK-born parent and, initially, wives of pers ons who were thems elves commonwealth citizens. ${ }^{56}$

\subsection{Conclusion}

The tension between the historical national image of liberal immigrant policies and high social pressures due to large inflows of aliens has produced many debates as to whether immigration policies should be tightened. ${ }^{57}$ There are underlying similarities throughout the historical pattern of British political response towards immigration acts. Immigration always provoked strong public resentment, especially due to the increased burden on housing and employment. The initial response was to maintain the traditional national self-image by maintaining liberal immigration policies, although this resulted in a struggle to meet the increased welfare demands. It was therefore deemed necessary to modify the immigration policies to take into account of the pressures felt by the whole nation. As a result, more rigorous immigration legis lation was introduced. The UK's immigration his tory reflects the state's maintenance of the social welfare of its domes tic citizens and the public interest as its primary policy consideration. It is also consistent with the belief that the development of international investment should not interfere with the justified public interest of the state and the human rights of its nationals.

\section{REGULATIONS ON THE ACQUISITION OF LAND BY ALIEN ENEMIES: A NATIONAL SECURITY PERSPECTIVE}

National security concerns during war-time, as the highest priority issue for any state, provide the strongest rationale behind a government's confis cation of assets owned by the residents of en emy countries. However, this is an exception limited to periods ofdeclared war.

The provis ions of the Trading with the Enemy Act 1939 were intended to prohibit commercial or financial dealings with the enemy and to preserve enemy as sets in the UK in order to prevent the enemy frombenefiting from them. Section 7 of the act required the Board of Trade to appoint custodians of enemy property so that the UK could preserveenemy property in contemplation of an arrangement being made at the conclusion of the war. ${ }^{58}$ The expression "property" was taken to mean any estate or interest in real or personal property ${ }^{59}$ It conferred on the custodians full powers of acquisition and discharge with respect to the property.

After the war, the assets of the occupied countries retained by the British government were widely released, except for those dis tributed to British creditors who had failed to obtain the return of their confis cated assets in enemy territories. ${ }^{60}$

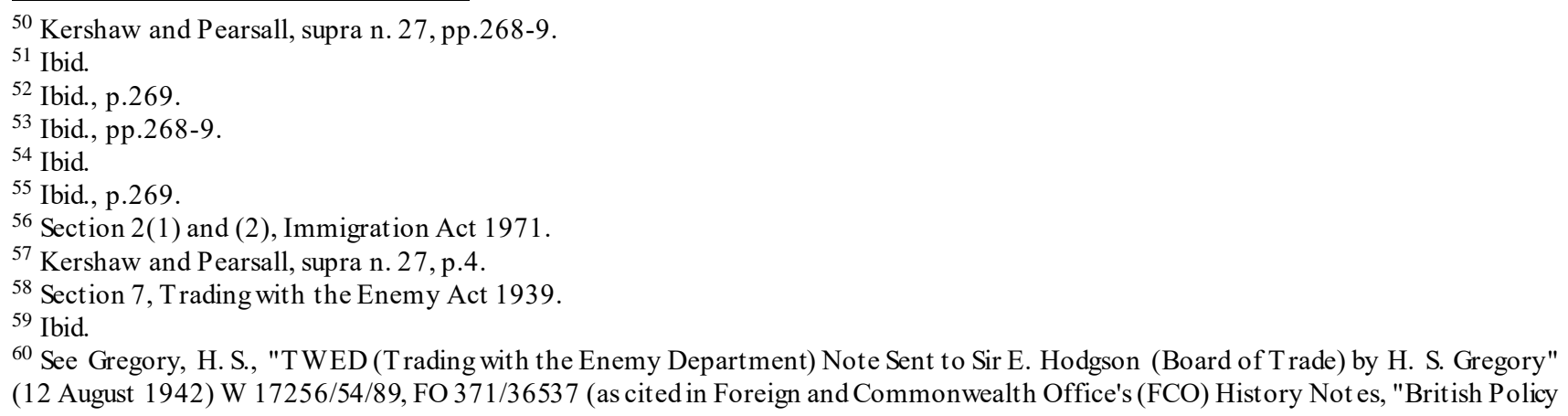


To facilitate the claims of aliens after the world war, the British government even launched a special compensation scheme and established an independent panel to administer the program (The panel was initially called the Enemy Property Compensation Advisory Panel and later known as the Enemy Property Claims Assessment Panel (EPCAP)). ${ }^{61}$ A claim could be made in respect of any property in the UK that had been confiscated under British legis lation regarding enemy property or trading with theenemy.

\section{CONCLUSION}

This article examines the general framework of UK alien land law and has come to the conclusion that land may not be identified as a symbolof political power and a privilege to acquire may not be granted only to fully allegiant subjects, or nationalcitizens. Firstly, land did act as the key to political privilege in British history but this was an idea originating and lasting only in the feudal period, during which time land was the principal social wealth indicator and political power was the only way to exercise distribution of the social wealth. Land was incorporated with a political identity and was only available to the feudal subjects of the Crown. Aliens were prohibited from purchasing, hold ing and inheriting land for quite a long period. However, the growing demand for residing in and running businesses in the UK from aliens wishing to develop trade with the country, pushed the state to relaxits restrictions on alien land possession, at first applying this only to friendly aliens, for regulated purposes and defined periods, but soon carry ing out a full liberalization, in 1870, under the Naturalis ation Act. Since then, the political image of land has been replaced by its economic character. Secondly, the history of UK alien land law overruled the traditional understanding of allegiance, which was define d as the exclusive characteristic of the national citizen. Allegiance, even during the feudal period, acted as an instrument to facilitate the changing so cial interests of the state, rather than as a traditionally-declared value. National citizens are also increasingly identifying themselves as separate or external to their nationals tate for a variety of purposes. For example, the attractive taxpolicies offered for non-domiciled UK residents before the introduction of theFinance Act 2008, made some wealthy Britons seek a connection with foreign states in order to declare themselves non-domiciled, further confirming the changed context of allegiance. $^{62}$

The UK is identified as having created the mostliberalized environment in the real estate industry for its foreign investors. It might have been the earliest country to confer on aliens the full extent of land ownership. It released land ownership as early as 1870 and since then has imposed no legal restrictions on alien land possession.

It is argued in the context of human rights protection that the state has to consider not only investors' free access to the domestic real es tate market but als o the housing demands of national citizens. In other words, market libe ralization has to be introduced in a manner consistent with secure and peaceful lives for local inhabitants. The immigration policy history of the UK was developed in quite a similar way. The pressure on housing and employment conditions due to large numbers of immigrants and the need to secure the housing welfare of national citizens prompted the enactment of several important immigration acts before the 1970s. The fulfillment of the housing rights of its national members is taken as one of the state's responsibilities towards their welfare.

In the foregoing theoretical parts, it is also suggested that the state may, without prejudice to the general approach of liberalization, adopts measures necessary to protect its essential security interests, which has been evidenced by the legal acts conducted by the UK against alien enemies.

towards Enemy Property during and after the Second World War" (April 1998) ISBN 0 903359 758, p.18).

${ }^{61}$ FCO History Notes, ibid., pp.39-49.

${ }^{62}$ Schedule 7 para. 90(3) and (4), Financial Act 2008. 